\title{
ENFORCEMENT OF CRIMINAL PENALTIES AND IMPRISONMENT: COMPARISON OF LEGAL SYSTEMS
}

DOI: 10.47743/rdc-2018-2-0001

Marco BUCCARELLA ${ }^{1}$

Andrea MARINO²

Wanda NOCERINO ${ }^{3}$

\section{Abstract}

This paper focuses on criminal penalties and imprisonment, comparing Romanian and Italian legal systems. In a setting where a growing number of EU countries are sentenced by the European Court of Human Rights due the violation of the Article 3 of the ECHR, it makes an attempt to describe the common problems and the existing diversities between European penal institutions. In particular, on the basis of these explorations, it discusses the inhuman and degrading treatment inflicted on people in prison overcrowding situations, as well as the violation of their human rights not justified by the purposes connected with the enforcement of judgements.

Moreover, this paper aims to show, in a de jure condendo perspective, some solutions to the "evils" of the judicial systems, based on rehabilitative and social reintegration purposes typical of criminal penalties.

To give a complete overview concerning this concrete question, the authors have chosen a multidisciplinary approach that ranges from international and comparative law to criminal and penitentiary procedural law. The hope is that this paper may contribute to the international debate.

Keywords: Criminal penalties; prison overcrowding; penitentiary rules; human rights; romanian law; italian law

\section{A growing concern for Prison System}

The topic of the role assigned to the penal sanction and to its enforcement has recently acquired increasing attention due to the consequences of the penalty on the fundamental rights on which rests democratic legal systems. Indeed, it is striking that the importance of the issue is determined by a series of failures recorded in different European countries - including Italy and Romania - due to the violation of the Article 3

\footnotetext{
${ }^{1}$ Sections 2, 3 Marco Buccarella, Expert in international law.

${ }^{2}$ Sections 6, 7 Andrea Marino, Expert in criminal law procedure.

${ }^{3}$ Sections 1, 4, 5 Wanda Nocerino, PhD student.
} 
of the European Convention on Human Rights (ECHR), for inhuman and degrading treatment inflicted on people in prison overcrowding situations, as well as for the violation of their human rights not justified by the purposes connected with the enforcement of judgements.

The prison overcrowding - as stated by the European Court of Human Rights - is an element that constitutes a non-dignified condition for the human being, because it deprives people of a minimum living space. This causes great difficulty in carrying out any activity that makes prisoners' life not an empty waiting time but a chance of reintegrating into society. As recently claimed, «if the penalty must consist almost exclusively in the loss or drastic reduction of freedom, it certainly cannot compromise the dignity, the right to health and the right to life ${ }^{4}$.

Therefore, it seems indispensable to analyze the actual condition of the European penal institutions, in order to highlight the common problems and the existing diversities and to find, in a de iure condendo perspective, some solutions to the "evils" of the judicial systems.

In particular, this paper aims to describe the Italian detention facilities' condition in relation to what happens in other European States with particular reference to the Romanian legal system as tertium comparationis, in order to verify the compatibility of the European prisons with the constitutionally and conventionally guaranteed fundamental rights, as well as with the rehabilitative and social reintegration purposes typical of the criminal penalties.

Without wishing to anticipate what will be said later, it seems that the problem to be solved is very complicated because it has its roots in cultural prejudice and in public opinion. In fact, as is well known, people are not inclined to recognize a prisoner's rights to health and they are often indifferent and intolerant against those who violated the rules of social coexistence.

Due to the transversal nature of the issues, to tackle this topic we have chosen a multidisciplinary approach that ranges from international and comparative law to criminal and penitentiary procedural law, based on sharing individual professional skills and aimed of finding a complete solution to the problem.

\section{A brief overview of International Human Rights Law}

Before examining the prison overcrowding situations, it is useful to give a brief overview of what rights are recognized under international law to all human beings. They are, precisely, rights inherent in the dignity of every human being ${ }^{5}$ that cannot be given or taken away.

\footnotetext{
${ }^{4}$ ECHR, June 13, 2019, Viola vs. Italia, No. 77633/16.

${ }^{5}$ For a deeper analysis of the term "human dignity", see 0. Schachter, Human Dignity as a Normative Concept, in The American Journal of International Law, Vol. 77, No. 4, 1983, pp. 848-854.
}

\section{CONSTITUTIONAL LAW REVIEW}


A first reference to the human rights can be fine in the preamble of the Charter of the United Nations, adopted on 26 June 1945, which says "We the Peoples of the United Nations determined to save succeeding generations from the scourge of war, which twice in our lifetime has brought untold sorrow to mankind, and to reaffirm faith in fundamental human rights, in the dignity and worth of the human person". It was more than a solemn statement of revulsion at the massive destruction of World War II. Actually, it was an implicit statement of an argument made explicit three years later in the preamble to the Universal Declaration of Human Rights, which says that "recognition of the inherent dignity and of the equal and inalienable rights of all members of the human family is the foundation of freedom, justice and peace in the world". In simple words, the dignity of the human being was recognized as relevant to the international order and this represented a profound transformation of International Law.

Before World War II there was virtually no general international law of human rights and only development of the law on the jus in bello (conduct of international armed conflict) preceded that of international human rights law. In fact, the refinement of rules of humanitarian law of the treatment of prisoners of war anticipated that of rules of human rights law relating to the treatment of prisoners in peacetime ${ }^{6}$.

In the post-World War II period, international consensus crystallized around the need to identify the individual rights and liberties which all governments should respect, and to establish mechanism for both promoting countries' adherence to their human rights obligations and for addressing serious breaches. Therefore, most of what we now regard as "international human rights law" has emerged only since 1945, when human rights issues has taken on a prominent role in United Nations (UN) politics ${ }^{7}$.

Human rights, although already mentioned by USA and French "Declarations" in 1776 and 1789, have been recognized with approval of Universal Declaration of Human Rights, adopted on 10 December 1948. This was the first of four instruments used by UN to protect human rights; the other three being the International Covenant on Economic, Social and Cultural Rights, the International Covenant on Civil and Political Rights and the Optional Protocol to the latter. These instruments are known collectively as the International Bill of Human Rights.

Increased UN involvement in human rights matters has been mirrored by growing adoption of regional human rights instruments, as illustrated by the entry into force in

\footnotetext{
${ }^{6}$ The relevant law relating to the treatment of persons in the hands of a party to an armed conflict was codified in the Geneva Conventions (adopted 12 August 1949); Geneva Convention for the Amelioration of the Condition of the Wounded and Sick in Armed Forces in the Field 75 UNTS 31 (Geneva Convention I); Geneva Convention for the Amelioration of the Condition of Wounded, Sick and Shipwrecked Members of Armed Forces at Sea 75 UNTS 85 (Geneva Convention II); Geneva Convention Relative to the Treatment of Prisoners of War 75 UNTS 135 (Geneva Convention III); Geneva Convention Relative to the Protection of Civilian Persons in Time of War 75 UNTS 287 (Geneva Convention IV).

7 Especially because of the implications of the emphasis by Arab countries on human rights aspects of the Palestine question after 1967.
} 
1953 and subsequent evolution of the European Convention on Human Rights (which now concerns 45 countries and over 800 million people), the establishment of the Inter-American Commission on Human Rights in 1960, the entry into force of the American Convention of Human Rights in 1978 and the adoption of the African Charter on Human and Peoples' Rights in 1986 and the Arab Charter on Human Rights in 2004. In addition, there are a lot of resolutions and recommendations relevant to international human rights that have been adopted by the UN, other international organizations or conferences. Obviously these instruments are not directly binding in a legal sense, but they establish broadly recognized standards and are frequent invoked in connection with human rights issues. By the end of the 1950, United Nations, the Organization of American States and the Council of Europe had each established mechanisms for the promotion and protection of human rights, which included, as far as we are concerned, the European Court of Human Rights (ECHR). International human rights courts and monitoring bodies oversee countries' implementation of international human rights treaties.

Although the layers of protection vary from country to country, depending on the existence of a regional human rights system and each country's ratification of regional and universal instruments, international human rights law is a set of rules governing State behavior vis-à-vis individuals and includes positive and negative obligations for every country. This means that when countries ratify human rights treaties, they agree to both refrain from violating specific rights and to guarantee enjoyment of those rights by individuals and groups within their jurisdictions.

Human rights represent some collective and community interests of countries. In fact, the initial impulse and the decisive thrust for the development of erga omnes obligations are derived from the human rights sector. The customary norms and the treaties on human rights are paradigmatic examples of norms that contain erga omnes obligations: they force every country towards all the other countries. The legal asset protected by erga omnes rules is really important ${ }^{8}$, as it is a matter of collective values, whose injury gives rise to form of international responsibility "envers tous les ... membres de la communautè international"9. Therefore, the fundamental rights of the human person are among the values protected by the constitutive rules of erga omnes duties $^{10}$, as confirmed by the jurisprudence of the International Court of Justice, and establish obligations for the entire international community.

\footnotetext{
${ }^{8}$ On the nature of the rules of general international law producing erga omnes obligations and on their impact on the legal status of international responsibility, see P. Picone, Comunità internazionale e obblighi erga omnes, 2013.

${ }^{9}$ Barcelona Traction, Light and Power Company, Limited, in C.I.J. Recueil, 1970, 3 ss.

${ }_{10}$ G. Puma, Complicità tra Stati e organizzazioni internazionali nella violazione di obblighi erga omnes, in Diritto Pubblico Comparato ed Europeo, No. 1, 2019, p. 75.
} 


\section{Treatment of Prisoners and Human Rights}

The relationship between prisoners and human rights has not always been an easy one. In fact, some people think that if you violate society's rules by committing a crime, then you forfeit, inexplicably, your rights to society protections. However, human rights are an inviolable set of subjective legal situations that every country must guarantee to all human beings, including people who are so positioned as to be unable to remove themselves from the ambit of official action and abuse. This means that each person, including prisoners, has an autonomous sphere of action in which countries cannot interfere, except in the ways and in the cases established by law. In terms of international law, the recognition of a core of intangible principles implies the imposition of greater and more onerous obligations on countries and their domestic jurisdiction.

On the international scene the "Resolution for the prevention of crime and the treatment of delinquents", adopted by the United Nations Congress on August $30^{\text {th }}$ 1955, has held particular importance for the right of prisoners. It concerned "minimal rules" on treatment of prisoner, below which it was not possible to go. In the "Preliminary Observations", for the first time in the history a world-wide standard regarding the treatment of prisoners in prisons has been established for all countries adhering to the United Nations. They were the rights of all prisoners, whether entirely innocent of any offence or guilty of the most heinous. Human rights do not end at the point of incarceration.

The Convention for the Protection of Human Rights and Fundamental Freedoms ${ }^{11}$, better known as the European Convention on Human Rights, was the first european instrument to give effect to certain of the rights stated in the Universal Declaration of Human Rights and make them binding. Although not explicitly referred to prisoners, the Article 3 of the ECHR provides that "No one shall be subjected to torture or to inhuman or degrading treatment or punishment" and sets a line between lawful and unlawful State action. Thanks to the jurisprudential activity of the European Court of Human Rights, the Commission and the jurisdictional bodies of the Council of Europe, which have operated since the 1960s, from the Article 3 it is possible to explain the principles respected on the treatment of prisoners. In fact, as clarified by the Court, "under article 3 , the State must ensure that a person is detained in conditions which are compatible with respect for his human dignity, that the manner and method of the execution of the measure do not subject him to distress or hardship of an intensity exceeding the unavoidable level of suffering inherent in detention and that, given the practical

\footnotetext{
${ }^{11}$ Council of Europe, Convention for the Protection of Human Rights and Fundamental Freedoms, opened for signature in Rome on 4 November 1950 and came into force in 1953.
}

STUDIES AND ARTICLES 
demands of imprisonment, his health and well-being are adequately secured by, among other things, providing him with the requisite medical assistance"12. The positive obligation towards prisoners is declined in a wide range of provisions, such as the obligation to guarantee adequate and proportionate prison terms, the respect for the ECHR and finally the obligation to provide necessary medical assistance.

Obviously, among the rights of people in prison there is that to an amount of living space sufficient to safeguard their health. Indeed, the UN Human Rights Committee considers that a lack of adequate living space not only contributes to a violation of the right to dignity and humane treatment, but also to conditions that breach the rights to life and health ${ }^{13}$.

As the UN Committee against Torture has stated, the effects of prison overcrowding are horrific, sometimes amounting to inhuman treatment. Moreover, the Special Rapporteur on Torture has noted the impact of overcrowding on health, pointing out that "overcrowding exacerbates the inability of the staff to provide adequate ... health care to the detainees. It also makes it difficult to prevent the spread of infectious diseases"14.

The European Court has declared that a situation of "continuously, severely overcrowded [cells] ... in itself raises an issue under Article 3"15. Therefore, the Court considers the extreme lack of space as a central factor in its analysis of compliance of the applicant's detention conditions with Article 3 and that it is incumbent on the respondent Government to organize its penitentiary system in such a way as to ensure respect for the human rights and the dignity of detainees, regardless of financial or logistical difficulties.

The most detailed standards on that constitutes overcrowding come from the European Committee for the Prevention of Torture and Inhuman or Degrading Treatment or Punishment (CPT). In particular, the CPT has articulated minimum standards of personal living space in a detention establishment:

- Six square metres of living space for a single-occupancy cell and sanitary facility.

- Four square meters of living space per prisoner in a multiple-occupancy cell and fully-partitioned sanitary facility.

- At least two meters between the walls of the cell.

\footnotetext{
${ }^{12}$ Kudła vs. Poland, 30210/96, Judgment Grand Chamber of 26 October 2000, § 94.

${ }^{13} \mathrm{R}$. Lines, The right to health of prisoners in international human rights law, in International Journal of Prisoners Health, 2008, p. 32.

${ }^{14}$ Commission on Human Rights, Report of the Special Rapporteur, Mr. Nigel S. Rodley, submitted pursuant to Commission on Human Rights resolution 1994/37 Addendum: Visit by the Special Rapporteur to the Russian Federation, 16 November 1994, UN Doc. E/CN.4/1995/34/Add.1 para 41.

${ }^{15}$ Dvoynykh vs. Ukraine, 72277/01, Judgment of 12 October 2006, para 66.
} 
- And at least two and a half metres between the floor and the ceiling of the cell.

In addition, important guidelines that aim to eliminate overcrowding are also provided in the following rules and standards: the UN Standard Minimum Rules for the Treatment of Prisoners (Nelson Mandela Rules), which indirectly prohibit prison overcrowding by delineating minimum living standards in detention facilities; the UN Standard Minimum Rules for the Administration of Juvenile Justice (the Beijing Rules); the UN Rules for the Treatment of Women Prisoners and Non-custodial Measures for Women Offenders (the Bangkok Rules); and the UN Standard Minimum Rules for Non-custodial Measures (the Tokyo Rules), which directly address steps to avoid prison overcrowding ${ }^{16}$.

\section{The prisons and Europe}

In Europe, the issue of prisons overcrowding has been studied for several decades.

In 2006 the Council of Europe adopted the European Penitentiary Rules (EPR) ${ }^{17}$, principles that the European Court has used as minimum standards below which there is violation of human dignity's principle under the European Convention on Human Rights.

On April 3rd 2019, the Council of Europe published the Space I Report (Statistiques Penales Annuelles du Conseil de l'Europe $)^{18}$ containing the annual criminal statistics on the European prison system.

This study shows that the overall rate of detention in Europe decreased by $6.6 \%$ between 2016 and 2018, passing from 109.7 to 102.5 inmates per 100,000 inhabitants (Fig. 1).

\footnotetext{
16 J. Bullock, Growing Concern for Prison Overcrowding Among Human Rights Bodies, in penalriform.org, 2017.

${ }^{17}$ Recommendation R (2006) 2 of the Committee of Ministers to member states on European Prison Rules, adopted by the Council of Ministers on 11 January 2006, on the occasion of the 952nd meeting of the Delegates of Ministers. In particular, the Article 4 EPR establishes the important principle according to which «[L] the conditions of detention that violate the human rights of the detainee cannot be justified by the lack of resources». According to the aforementioned rules, detainees must be guaranteed the possibility of communicating and receiving from their family members from one to four visits a week and enjoying programs for their return to society after their release. It must also be ensured that, at the time of release, prisoners are provided with appropriate documentation and that they are assisted in finding accommodation and work; in reality this happens only in exceptional cases.

${ }^{18}$ From the questionnaire to which the penitentiary administrations of 47 States of the Council of Europe responded, some relevant data emerge. The SPACE Study is carried out on behalf of the Council of Europe by the University of Lausanne. SPACE I 2019 brings together information from 45 of the 52 penitentiary administrations of the 47 member States of the Council of Europe.
} 
Marco BUCCARELLA • Andrea MARINO • Wanda NOCERINO

Figure 1. Prison population rates (inmates per 100,000 inhabitants) on $31^{\text {st }}$ January 2018

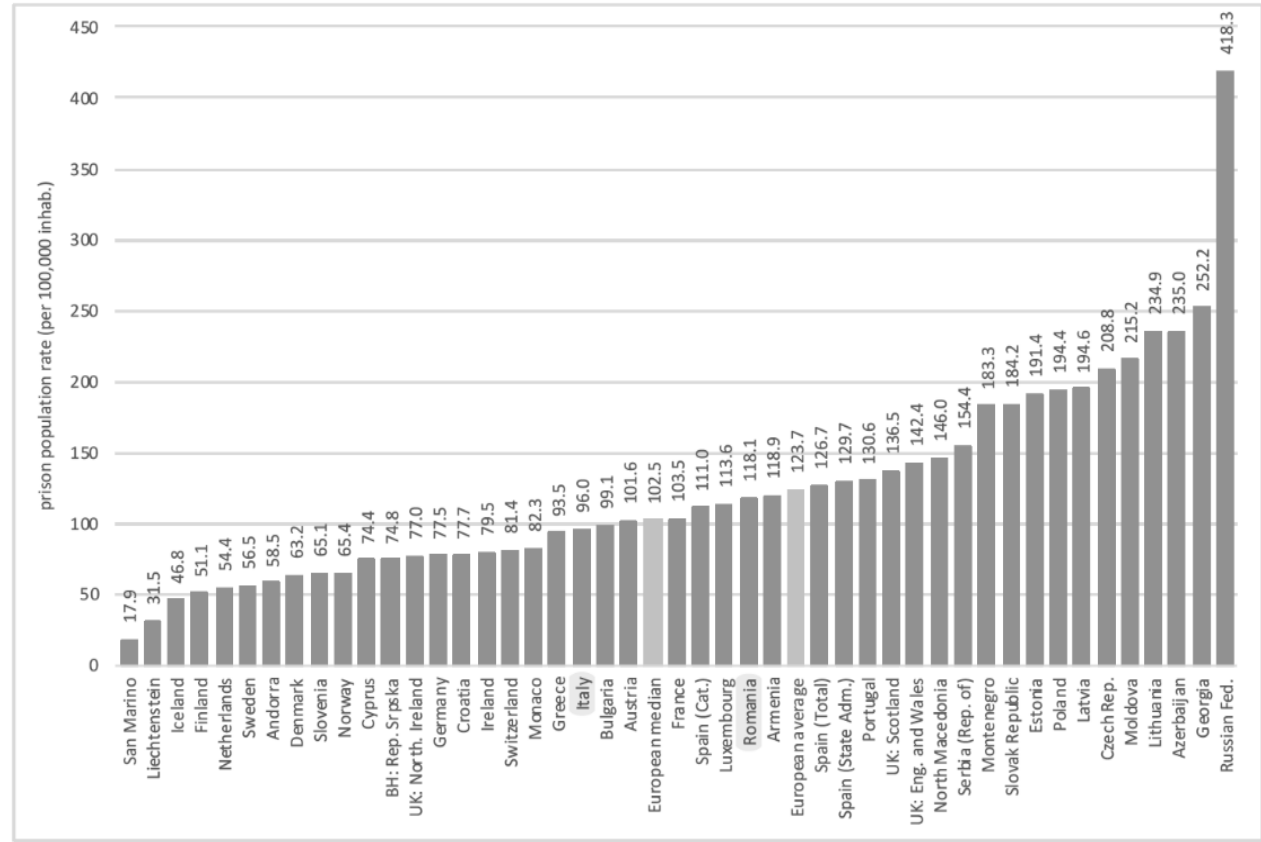

This contraction represents the continuation of a trend that began in 2012, when the detention rate, an indicator mainly determined by the duration of prison penalties, started to progressively decline. The contraction of the detention rate in 27 prison administrations in 2018 was accompanied by a reduction in the average length of detention, which fell from 8.8 to 8.2 months (-6.8\%) across Europe (Fig. 2). 


\section{Enforcement of criminal penalties and imprisonment}

Figure 2. Evolution of stock indicators (2016 to 2018) and flow indicators (2015 to 2017)

\begin{tabular}{|c|c|c|c|}
\hline & 2016 & 2018 & $\begin{array}{c}\% \text { change } \\
2016-2018\end{array}$ \\
\hline \multicolumn{4}{|l|}{ Stock indicators } \\
\hline Prison population rate (non-adjusted) (44 PA) & 109.7 & 102.5 & -6.6 \\
\hline$\%$ of female inmates (44 PA) & 5.4 & 5.0 & -7.4 \\
\hline$\%$ of foreign inmates $(41 \mathrm{PA})$ & 16.7 & 15.9 & -4.8 \\
\hline Of which: $\%$ of foreign inmates from EU countries (36 PA] & 29.2 & 32.3 & 10.6 \\
\hline$\%$ of non-sentenced detainees (43 PA) & 17.4 & 22.4 & 28.7 \\
\hline Prison density (43 PA) & 91.1 & 91.4 & 0.3 \\
\hline $\begin{array}{l}\text { Number of Overcrowded Prison Administrations (more than } 100 \text { inmates per } 100 \\
\text { places) ( } 42 \mathrm{PA} \text { ) }\end{array}$ & 9 & 12 & $(33.3 \%)$ \\
\hline Ratio of inmates per prison staff (40 PA) & 1.7 & 1.6 & -5.9 \\
\hline Ratio of inmates per custodian solely dedicated to custody (35 PA) & 2.9 & 2.8 & -3.4 \\
\hline \multicolumn{4}{|l|}{ Sentenced prisoners by offence } \\
\hline$\%$ of prisoners sentenced for drug offences ( $37 \mathrm{PA}$ ) & 17.6 & 19.3 & 9.7 \\
\hline$\%$ of prisoners sentenced for theft (35 PA) & 18.6 & 15.8 & -15.1 \\
\hline$\%$ of prisoners sentenced for homicide (37 PA) & 12.3 & 12.9 & 4.9 \\
\hline \multicolumn{4}{|l|}{ Sentenced prisoners by length of sentence imposed } \\
\hline$\%$ of prisoners sentenced to less than one year (38 PA) & 16.5 & 16.3 & -1.2 \\
\hline$\%$ of prisoners sentenced from 1 to less than 3 years ( $38 \mathrm{PA})$ & 26.5 & 23.5 & -11.3 \\
\hline$\%$ of prisoners sentenced from 3 to less than 5 years ( $38 \mathrm{PA})$ & 17.2 & 16.5 & -4.1 \\
\hline \multirow[t]{2}{*}{$\%$ of prisoners sentenced from 5 to less than 10 years ( $38 \mathrm{PA}$ ) } & 20.4 & 18.2 & -10.8 \\
\hline & 2015 & 2017 & $\begin{array}{c}\text { \% change } \\
2015-2017\end{array}$ \\
\hline
\end{tabular}

In the opposite direction, the percentage of prisoners in pre-trial detention has increased from $17.4 \%$ to $22.4 \%$ of the total prison population: as can be seen from the graph below (Fig. 3), Italy (113.4) and Romania (120.5) are among the countries where prison density it is particularly high. 
Figure 3

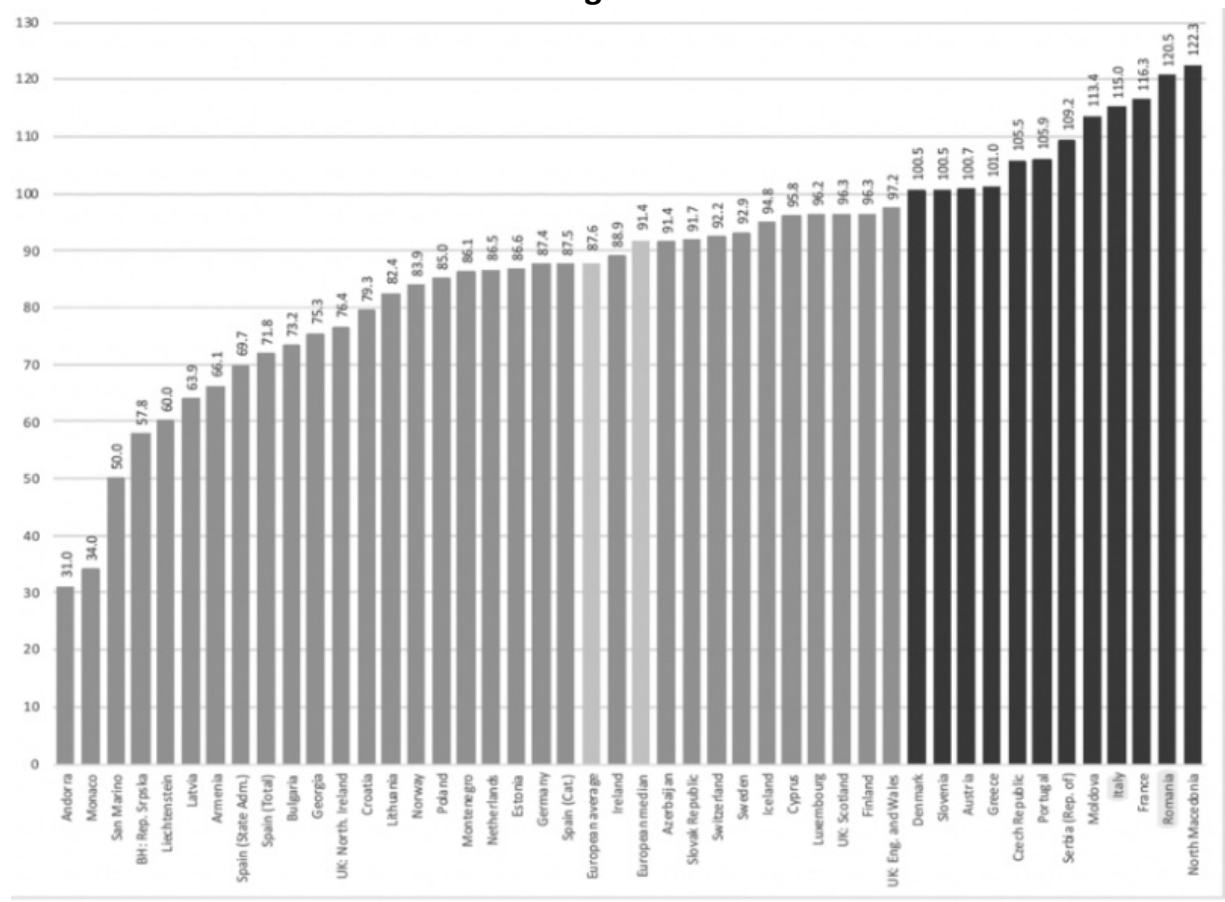

Hovewer, the increase in the prison population in Italy and Romania derives from different factors.

The Romanian legal system is characterized by being a highly punitive system with a tightening of penal sanctions in view of a security policy ${ }^{19}$, whereas the Italian legislative trend is based on the reduction of offences subject to criminal sanctions ${ }^{20}$.

According to what was said above, it emerges that the growth of prisoners is inversely proportional to the type of legal system existing in the two countries, because the prison emergency seems to be a common problem for both Italy and Romania.

\footnotetext{
${ }^{19}$ Recently, there have been several bills to change the Criminal Code in a punitive way, but the Constitutional Court found the unconstitutionality of the new proposals. For example, on 4 July 2018 the Romanian Parliament with a social democratic majority proposed some amendments to the penal code aimed at reducing the sanctity of the sanction in corruption crimes. Moreover, on April 24th, in a new form and with a lower number of proposals compared to the previous versions, the parliamentarians voted to amend and integrate the Law n. 286/2009 on the penal code, as well as the law n. 78/2000 (shortening of the statute of limitations, new provisions for the application of mitigating circumstances, reduction of the terms for the granting of conditional release), with the aim of strengthening the punitive system, confirming the logic of the system.

${ }^{20}$ Finally, by way of example, with the entry into force of the decriminalization (referred to in the decrees $\mathrm{n} .7$ and n. 8/2016) a long series of less serious crimes was canceled, with the aim of lightening the load of the proceedings in the courts and prosecution offices. There are as many as 41 cases that no longer have criminal relevance but that have turned into civil and administrative offenses punished with financial penalties, with the aim of obtaining a high deterrent effect. See $\S 4$.
} 
Enforcement of criminal penalties and imprisonment

The compatibility of italian and romanian prisons with european standards. Judgments from the European Court of Human Rights

The proof of insufficient compatibility of prison systems with European standards of guaranteeing respect for human life and inviolable rights derives from the numerous condemnations that the EDU Court has inflicted - and continues to inflict - on Italy and Romania for the violation of the Article $3 \mathrm{ECHU}$. In particular, the systematic prison overcrowding situation has led to the presentation of thousands of appeals by prisoners and internees who complain about the precarious living conditions inside the penitentiary institutions and relegate two countries to those with the highest number of complaints among the 47 members of the Council of Europe.

Curiously, the jurisprudential condemnation from the ECHR to the two countries followed the same temporal scan: drastic lack of attention to the problem of prison overcrowding until the first decade of the XXI century; first (and isolated) pronouncement of censorship at prisons between 2007 and 2009; repeated sentences of condemnation in the years 2012-2019 after the contemporary pilot judgments, respectively represented by the judgment in Torreggiani against Italy on 8 January $2013^{21}$ and Constantin Tudor against Romania on 18 June $2013^{22}$.

21 ECHR, January 8, 2013, Torreggiani and others vs. Italy, n. 43517/09, 46882/09, 55400/09, 57875/09, 61535/09, 35315/10 and 37818/10. The case concerns seven appeals filed between 2009 and 2010 by as many detainees, three Italians, two Moroccans, one Ivorian and one Albanian, who complained that they had suffered inhuman and degrading treatment. In fact, they had been held in nine square meter cells, to be shared with two other people, for periods ranging from 14 to 54 months, between 2006 and 2011. They also complained that the cells were poorly lit and that access to the hot water for showers was limited. Although all the applicants less one were now free at the time the Court ruled, they did not for this reason lose the quality of "victims" of the alleged violation of the Article 3 ECHR (see $\S \S 36-40$ ). The Court, having ascertained the violation, orders a fair pecuniary compensation in favor of the applicants. In some cases, the judges fully accepted the applicants' requests or reduced them to a modest extent (compensation between 10,600 euros and 15,000 euros); in other cases, they attributed a certain sum to applicants who had relied on the evaluation of the judges $(23,000$ euros for the Ivorian applicant); in the case of one of the applicants who had asked for compensation of 30,000 euros for a stay in a cell in a degrading treatment condition of 17 months, the Court attributed it only 12,500. Altogether the State is obliged to pay around 96,000 euros. Modest sums (1,500 euros each) were attributed by way of reimbursement of legal expenses only to the plaintiffs who availed themselves of the representation of lawyers. The three applicants who had been authorized to defend themselves alone did not receive any reimbursement for legal expenses.

${ }^{22}$ ECHR, June 18, 2013, Constantin Aureliano Tudor vs. Romania, appeal n. 43543/09. Constantin Aureliano Tudor is a Romanian citizen who was sentenced to 12 years in prison for trafficking in human beings in 2004 (a verdict also confirmed in Cassation). In 2008 he was placed in the prison of Jilava, a penitentiary known as "a place of torture and physical and mental terror due to inhuman and degrading conditions of detention". The prisoner was soon able to see on his skin the veracity of what might have seemed a simple rumor. In fact, in October 2008 the applicant filed a complaint with the competent Court for the enforcement of judgments, in relation to the conditions of detention suffered at the Jilava prison and the lack of adequate medical care. Specifically, the Romanian detainee complained the presence of parasites in the prison cells, the poor quality of food and water, the lacking facilities for personal hygiene and, in general, the precarious and not dignified living conditions in which they were relegated the inmates. The Court, rejecting the Government's objections, stated that the conditions of detention of Mr. Tudor in the penitentiary of Jilava are to be considered inhuman and degrading and ordered Romania to pay moral compensation of $€ 3.000,00$ to the applicant.

STUDIES AND ARTICLES 
With regard to the Italian system, more than ten years after the first ruling that stated the violation of the art. 3 ECHR for prison overcrowding ${ }^{23}$, on 8 January 2013, Italy was condemned by the Court for inhuman and degrading treatment suffered by seven people detained for many months in the prisons of Busto Arsizio and Piacenza, in triple cells and with less than four square meters each available.

In the same way, Romania is also involved in the phenomenon of degrading conditions of detention caused by overcrowding. A few years after the isolated ruling ascertaining the infringement of the right pursuant to Art. 3 ECHR against the Romanian citizen Alexander Bragadireanu ${ }^{24}$, on 18 June 2013 the European Court stated that the inhumane conditions of the prisons in which Mr. Constantin Tudor has been imprisoned integrating the violation of the conventional rule aimed at protecting fundamental rights $^{25}$.

From 2013 forward, which represented "a year of fire" for the two countries suffering simultaneously the most severe condemnation by the European Court of Human Rights for the penitentiary treatment of prisoners, a domino effect is determined and have followed over 100 sentences of condemnation to both Romania ${ }^{26}$ and Italy ${ }^{27}$.

23 ECHR, July 1,6 2003, Sulejmanovic vs. Italy, n. 22635/03. The story concerns a Bosnian citizen, Izet Sulejmanovic, convicted of stealing, receiving stolen goods and forgery, who is arrested on 30 November 2002 while he was in Rome to obtain a residence permit. The Sulejmanovic has to stay in Rebibbia prison (Roma) for a total of one year, nine months and five days. In July 2003, this Rebibbia prison housed 1,560 people although its reception capacity was limited to 1,271 people. The Sulejmanovic is enclosed in several cells, all of $16.20 \mathrm{~m}^{2}$ to which a sanitary room of $5.04 \mathrm{~m}^{2}$ is connected. Sulejmanovic from the beginning of his detention until April 15,2003 shares the cell with five other people. Therefore, each prisoner has an average area of $2.70 \mathrm{~m}^{2}$. From 15 April to 20 October 2003, the Sulejmanovic is transferred to another cell, shared with four other people and where each prisoner has an average area of $3.40 \mathrm{~m}^{2}$. The ECHR states that the obvious lack of a personal space is in itself an inhuman or degrading treatment. Therefore, according to the ECHR, for that period there has been a violation of Article 3 of the Convention.

${ }^{24}$ ECHR, December 6, 2007, Alexander Bragadireanu vs. Romania, n. 37075/14.

25 «[L] to imprisonment - affirmed by judges of Strasbourg - does not make the prisoner lose the benefit of the rights enshrined in the Convention. On the contrary, in some cases, the imprisoned person may need greater protection precisely because of the vulnerability of his situation and because he is totally under the responsibility of the State. In this context, article 3 places a positive obligation on the authorities which consists in ensuring that every prisoner is detained under conditions compatible with respect for human dignity, that the methods of execution of the measure do not subject the person concerned to one state of despondency or to a test of intensity that exceeds the inevitable level of suffering inherent in detention and that, given the practical needs of imprisonment, the health and well-being of the prisoner are adequately insured». Thus the ECHR, June 18, 2013, Constantin Aureliano Tudor vs. Romania. In the same sense, ECHR, January 8, 2013, Torreggiani and others vs. Italy.

26 ECHR, September 17, 2013, Olariu vs. Romania, n. 12845/08; April 30, 2013, Ion Ciobanu vs. Romania, 67754/10; March 26, 2013, Györgypal vs. Romania, n. 29540/08; March 19, 2013, Blejusca vs. Romania, n. 7910/10; March 5, 2013, Geanopol vs. Romania, n. 1777/06; March 5, 2013, Stana vs. Romania, n. 44120/10.

27 ECHR, February 23, 2014, Placì vs. Italy, appeal n. 48754/11; September 24, 2015, Paolello vs. Italy, n. 37648/02; February 23, 2016, Nasr and Ghali vs. Italy, n. 44883/09; October 12, 2017, Tiziana Pennino vs. Italy, n. 21759/15; October 26, 2017, Azzolina and Others vs. Italy, n. 28923/09 and 67599/10; October 25, 2018, Provenzano vs. Italy, n. 55080/13; January 24, 2019, Knox vs. Italy, n. 76577/13; June 13, 2019, Viola vs. Italy.

CONSTITUTIONAL LAW REVIEW 


\section{The italian penitentiary system: the main reforms ante}

\section{and post "torreggiani"}

The "Torreggiani" judgement represents sine dubio a "zero year" for Italy.

In fact, through this statement the Strasbourg Court has not only highlighted the problems of the Italian prison system, but has required an important "change " to solve the prison overcrowding. This warning was accepted by the Government which took note of the distressing situation of its penitentiary institutions, as well as the ineffectiveness of the measures taken by the State up to that time.

In particular, it should be noted that the regulatory interventions in the "ante-Torreggiani" period were in the only direction of reducing the number of people already in prison. It represented an attempt to stem the phenomenon "downstream", and not even "upstream" by intervening on the influxes of prisoners in prisons. In this regard, among the most significant reforms we can find the indulto law entering into force with the law n. 241 of 31 July 2006, as well as the law n. 199 of 26 November 2010, better known as "Svuota Carceri"28.

With the Law of 2006, the "Prodi" Government, through the introduction of the "indulto" as a cause of extinction of the punishment, applied a discount of punishment not exceeding three years on all the crimes committed up to May 2, 2006, with limitations for those people who had committed crimes of particular social alarm.

This institute, like the "amnestia", involved a sort of "pardon on punishment" and aimed fundamentally at reducing the already high number of prisoners. In the same perspective the law "Svuota Carceri" of 2010, which precisely allowed the possibility to serve the last twelve months of imprisonment at home or in another public or private place of care, assistance and reception. This legislative provision intervened after the Sulejmanovic judgment vs. Italy and the objective, previously explicit, was to favor the early exit of prisoners from prison institutions. Except that, both the novella of 2006 and that of 2010, failed in their intent, because the rate of prison population from those years onwards has increased and not decreased ${ }^{29}$.

The need to implement concrete interventions came after the "Torreggiani" decision. The "change of course" requested by the Strasbourg Court has certainly happened, at least in the elaboration of measures aimed at managing and containing the new entries in Italian prisons. The years of imprisonment in the custodial measure

\footnotetext{
${ }^{28}$ See F. Della Casa, “Approvata la legge c.d. svuota-carceri: un altro "pannicello caldo" per l'ingravescente piaga del sovraffollamento carcerario?", in Dir. pen. proc., 2011, p. 5.

${ }^{29}$ From 2010 until 2013 (before the "Torreggiani" judgment), a series of regulatory interventions followed in order to expand the scope of these measures and in particular the "Svuota carceri". For all see decree n. 211 of December 22, 2011, converted with modifications by the Law February 17, 2012, n. 934, with which the penalty limit within which home detention introduced in 2010 was raised to eighteen months
} 
have been brought from a maximum of four to five (art. 280, comma 2 c.p.), trying to limit the recourse to $\mathrm{it}^{30}$.

In addition, the Corte Costituzionale declared the partial constitutional illegitimacy of the Law October 9, 1990, No 309, better known as the "Legge Fini-Giovanardi" with which the sanctions relating to the conduct of production, trafficking, illegal detention and use of drugs were tightened and which provided for the simultaneous abolition of any distinction between soft drugs and hard drugs ${ }^{31}$. The intervention of the Court has certainly had a positive impact on the reduction in the number of convicts for drugs.

Finally, the highest point of attention on the phenomenon of "prison overcrowding" has probably been by Italian Legislator with the recent Law n. 103 of June 23, 2017, better known as "Riforma Orlando". This law - only partially approved by the current Italian Government - appeared at least theoretically to be a "well-designed" reform ${ }^{32}$, as it was capable of intervening organically on the entire subject of penitentiary law. It was the result of a different approach to the "prison system", made possibile by the involvement of the States General of the penal execution, which brings together the experts of the sector.

Moreover, the reform was intended to intervene on the system of foreclosures and on automatisms in penitentiary treatment, trying to mitigate, for example, the application of "life without parole", that is the form of "never ending penalty" without semi-freedom and/or probationary conditions; on the other hand, there were more possibilities for prisoners to access alternative measures to prison even for those who had a residual sentence of up to 4 years ${ }^{33}$.

However, that imagined reform has not implemented with the advent of the "Conte" Government. The current Italian executive body appears to be driven by diametrically opposed ideas to those that inspired the mentioned reform of the penitentiary system - just think of the tightening of penalties provided for by the anti-corruption law n. 3 of 9 January 2019, better known as the "Legge Spazza-corrotti". Therefore, some experts of the sector speak about a rediscovered prison-centric vision of the system, based on the crime and not on the person.

\footnotetext{
30 Until April 30, 2015, 9,308 prisoners (Italian and foreign) awaiting first instance judgment; those not definitive (because appellants or applicants) were 9,108, demonstrating the high rate of subjects held in place of precautionary measures. See Mangiaracina, "Italia e sovraffollamento carcerario: ancora sotto osservazione", in Dir. pen. cont., No. 1, 2015, p. 415.

${ }^{31}$ Corte Costituzionale, February 25, 2014, No 32, in www.dirittopenalecontemporaneo.it.

32 Dolcini, La riforma penitenziaria Orlando: cautamente, nella giusta direzione, in Dir. pen. cont., No. 2, 2018, p. 180.

33 Polidoro, L'auspicata riforma dell'ordinamento penitenziario, in AA.VV. La Riforma Orlando - I nuovi decreti, ed. SPANGHER, in Nuove leggi Nuovo diritto, 2018, p. 367 ss.
} 


\section{Enforcement of criminal penalties and imprisonment}

\section{Conclusions. Alternative measure to detention and the good example}

\section{of italian "Probation"}

In conclusion, Eouropean countries should work to resolve the prison overcrowding problem.

In this respect, since the entry into force of the Law of 26 July 1975, No. 354, the Italian penitentiary system has adopted a system of alternative measures to detention. The purpose of that law is to make rehabilitative function of the penalty, prescribed by the Italian Constitution under Article 27 Cost., and to affect the enforcement of the main custodial sentence. In Italy, these measures are as follows: probation service to the social service (art. 47 ord. pen.); probation (art. 48 ss. ord. pen.); house detention (art. 47 ter ord.pen.).

With regard to these reward mechanisms, the following study carried out by the Antigone political-cultural association in the IV report is useful to understand the conditions of detention in Italy:

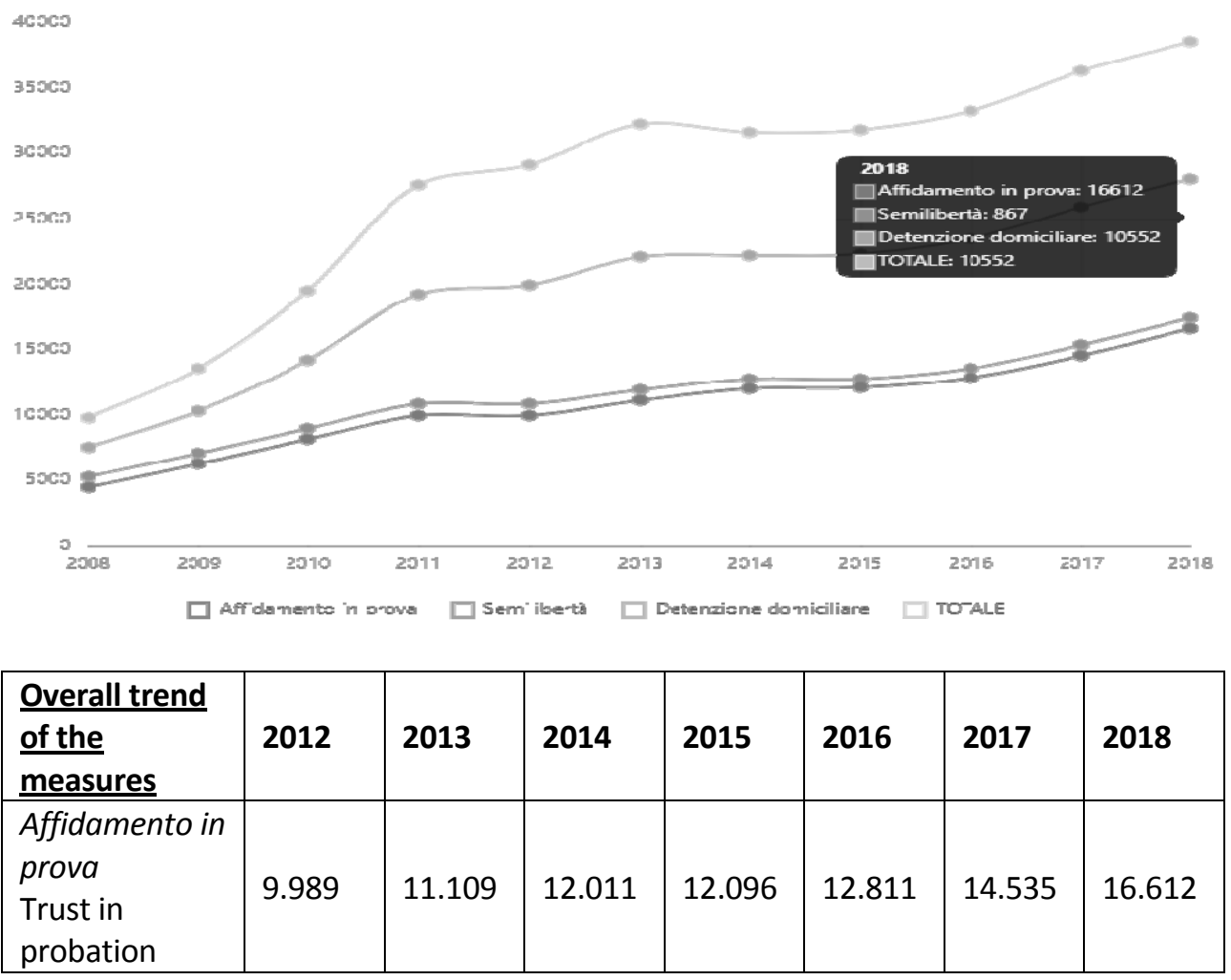


Marco BUCCARELLA • Andrea MARINO • Wanda NOCERINO

\begin{tabular}{|l|l|l|l|l|l|l|l|}
\hline $\begin{array}{l}\text { Semilibertà } \\
\text { Semi-liberty }\end{array}$ & 858 & 845 & 745 & 698 & 756 & 850 & 867 \\
\hline $\begin{array}{l}\text { Detenzione } \\
\text { domiciliare } \\
\text { Home } \\
\text { detention }\end{array}$ & 9.139 & 10.173 & 9.453 & 9.491 & 9.857 & 10.487 & 10.552 \\
\hline
\end{tabular}

As can be seen in the figures above, from the year 2012 up the alternative measures to detention have had a growing trend of use by prisoners. This is the proof that alternative measures to detention are a useful tool for disposing of the number of prisoners in prisons, especially those entering ${ }^{34}$.

In Europe, there is a great interest on mechanism of "Probation", that consists of a series of activities and interventions, which involve monitoring, consulting and assistance, with the aim of socially reintegrating the criminal into society and contributing to collective security ${ }^{35}$. "Probation" is already recognized by several European countries, including Italy and Romani.

In Italy, probation corresponds to the institute of "messa alla prova", introduced with the Law of 28 April 2014, No. 67. This is a special criminal procedure that involves the suspension of the proceeding against the suspect/accused, if the trial period to which the latter accesses - admitted by the judge in the presence of certain requirements - ends with a positive result. The "Italian probation" had already been tested with reference to the juvenile criminal trial and now the procedure shall apply also to adult - if thery agree - who have committed crimes with a custodial sentence not exceeding four years.

Referring to the prison overcrowding, this special procedure has been - after the judgment Torreggiani - a concrete and urgent response to European expectations about the need to reform the sanctioning system. The impact of this institute on Italian law system is certainly positive, because it satisfied everyone, both those who claimed an effective sanction response and those who hoped for the introduction of a suitable instrument to have a significant impact on the prison system.

In conclusion, the "Italian Probation" could be seen as "best practice" to be exported to other European countries.

\footnotetext{
${ }^{34}$ In fact, as Antigone explains " $[\mathrm{I}]$ In the absence of this positive trend in alternative measures, the number of prisoners would probably have grown more, but this does not means that it is difficult to explain the growth of prison presences in these years by looking at the system of alternatives to detention, which continues to expand".

35 See the Recommendation on the Council of Europe's rules on probation, CM/Rec (2010), Committee of Ministers of the Council of Europe.
} 